\title{
The Detection of CD95L at serum of patients with Molluscum Contaginosum (MCV-1)in Babylon/ Iraq.
}

\author{
Received : 7/12/2017
}

Accepted : 18/1/2018

\section{Nisreen Kaddim Radi ${ }^{1}$, Zainab A. Tolaifeh ${ }^{2}$, Hawraa Jawad Kadhim ${ }^{3}$, Israa Adnan Ibraheam $^{4}$ and Shaima Ahmed Rahim ${ }^{5}$}

\author{
1,2,3,4,5University of Babylon, College of Science for Women, Department of Biology, Iraq \\ *zainabalnassrawi.za@gmail.com
}

\begin{abstract}
$\underline{\text { Abstract }}$
The aim of this study was to investigate the predominant type of MCV in children and adolescents who consulted Murjan Educational hospital in Babylon/ Iraq and to detect CD95L concentration during the infection. A total of thirty MCV patients and twenty two healthy persons were selected for viral, histological and immunological tests by using histological, PCR and ELISA techniques. The results were revealed that : $99 \%$ of patients of MC proved positive PCR, MCV-1 is the predominant type including high infection rate in children with age group $(<10)$. The concentration of CD95L was highest in patients sera compared with control group. There was significant Mean Differences of FSAL Concentration by MCV's location especially at the hand and face. The results showed that mean SD of CD951 at patients whom have pervious MCV less than one year of infection have higher percentage of infection with increased of CD951 level, while CD951 concentration at patients with MCV lesion more than one year.
\end{abstract}

Key words : MCV,CD95L, children, adolescence, immune compromised.

\section{Introduction}

Molluscum contaginosum virus infection stimulate self-limiting shiny lesions in the human skin, these viruses are classified from 1 to 4 ; MCV-1 is the most common and prevalent in adults, and cause sexually transmitted diseases. Infection is common in children between 1 and 4 years old[ 1]. MCV viruses can affect any region of the skin more than the trunk, arms, joint, legs and towels. The virus usually spreads by contact from the skin to the skin. This includes sexual contact with skin that infected with viral lesion, skin scraping, touching infected skin, and use of contaminated items (fomite)[2]. The virus can spread among children in the nursery or in school[3-4]. MCV disease appears in the form of a bubble or a single fleshy bulge or multi-red color or glossy white, dome-shaped, pearly in appearance. The size of the wart is $1-5 \mathrm{~mm}$ in diameter, with a small center[1]. The injury occurs in the skin to the face, hands and legs, but the patient may transfer the viral cells carrying the virus to other areas such as the reproductive tract, the uterus and other parts of the body. When the virus reaches the lower layers of the skin, it begins to multiply[5-6]. MCV disease is a skin disease that affects children and immune compromised people. It is described as self-limiting disease because the lesion resolved after one or two years of infection[7] cellular Immunity is responsible for resisting $\mathrm{MCV}$ virus, which stimulates programmed apoptosis and necrosis of infected cells T-cell[8]. One of the results of these processes is the Fas ligand protein (CD951), the second type of Tumor necrosis factor (FAS ligand). In human this protein consists of $8 \mathrm{~kb}$ divided into 4 parts called exon and the interaction of the receptor for CD95L gene play an important role in regulating the immune system and resulting in the controlling of cancer development, after stimulating the gene and the production of protein Fas ligand this will enhance the Trimerizatin, which lead to necrosis and killing of viral infected cells [9]. 


\section{Materials and Methods}

A total of 30 specimens were collected from the blood and the tissue that accurate from the site of MC infection patients who consulted the dermatology department clinic of the Murjan Educational Hospital and 22 blood specimens were collected as control group from healthy individuals persons. The diagnosis was based on the phenotypic characteristics of the MCVinfected tissue by dermatologist and by using PCR technique. The glass slides were examined for changes in tissue by using optical microscopy to observe cytopathic effects by the virus in the tissue[10]. The examination of sera samples were done by using the Fas ligand immunosorbent assay (ELISA test) according to the instructions of the manufacture company (Boster Biological Technology Company).

\section{PCR technique:}

Conventional Polymerase chain reaction was used to detect the Molluscum contagiosum virus, and restriction enzyme Bam.HI to type Results and Discussion:

\section{Histological study of Molluscum contaginosum}

The histological study of MCV-infected skin assured the results of the clinical diagnosis and PCR test. The presence of islands flexible multilayered epithelial tissue and corpuscles on keratinocytes, which are rarely surrounded by inflammation under the microscope as shown of virus. Thirty tissue specimens were collected from patients depend on the size of lesion, after DNA extraction the purification of DNA was done as instructed by the Geneaid company , primer that were used in this study

F1

(5-GGCGCGTAGCCGAGCGG-3)

R1(5 CTTCCGGGCTTGCCGCCGGGCAG-3) (393-bp) from Bioneer, to detect Molluscum contaginosum virus. The samples were used with a thermal stages concerning initial denaturation: 1 cycle at $95^{\circ} \mathrm{C}$ for 1 minute, 40 cycles of $\left[95^{\circ} \mathrm{C}\right.$ for $1 \mathrm{~min}$ ( denaturation), $58^{\circ} \mathrm{C}$ for $1 \mathrm{~min}$ ( annealing), $72^{\circ} \mathrm{C}$ for $1 \mathrm{~min}$ (extension), and 1 cycle at $72^{\circ} \mathrm{C}$ for 5 minutes, keep the reaction for $5 \mathrm{~min}$ at $4^{\circ} \mathrm{C}[11]$.

\section{Statistical analysis:}

The analysis was done by using SPSS variety 20.0.The normal distribution was conformed correlation analysis, independent t-test was used to estimate differences between two groups in continuous variable. Result are reported as mean and standard deviation (mean $\pm \mathrm{SD}$ ) unless otherwise indicated. A p-value of $\leq 0.05$ was considered as a lowest limit of significant[12]

in figure 1. The multi-layered of the edema contain islands in which have many bodies of the MCV virus, called molluscum bodies or hinderson Patterson bodies, are classified as a diagnostic feature of viral infection[10],[13-16].

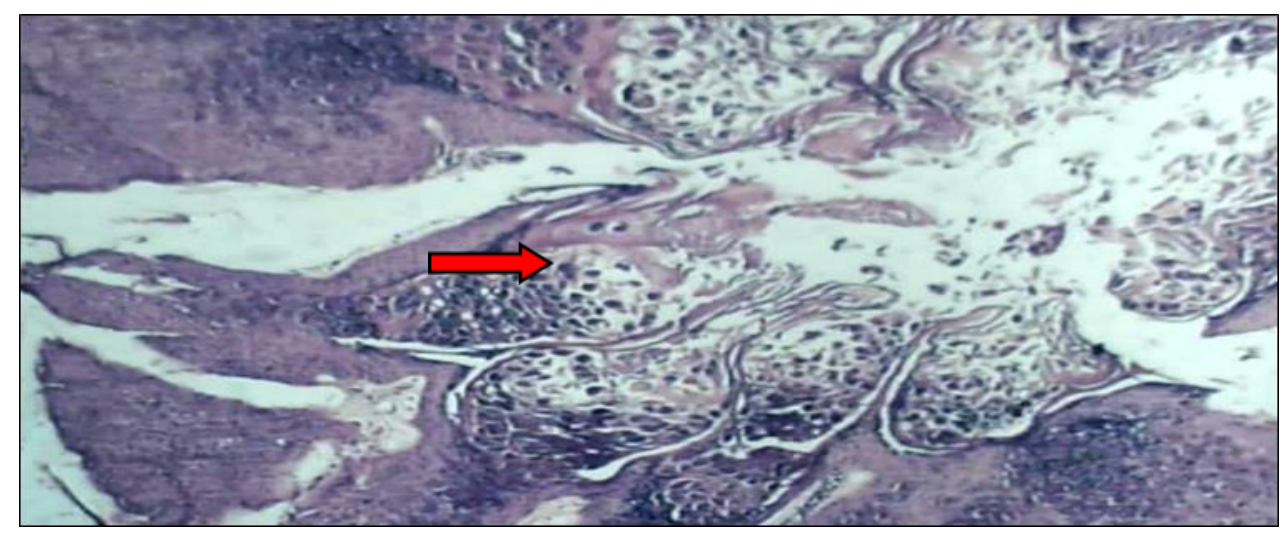


Fig (1): Transverse section of the skin of patient infected with the MCV virus shows cytopathic effects produced by MCV virus, where the epidermis acanthotic is thickened and a large number of epidermal cells contain bodies within a large cytoplasm called the Molluscum bodies( row) (hematoxylin-eosin 10x)

\section{Distribution of patients with MCV by age groups}

Thirty patients with MCV lesions who consulted dermatological department clinic of Murjan Hospital. About 48.0\% of patients were younger than 10 years as shown in (Figure 2). The study revealed that the higher infection rate with MCV about $48 \%$ was related to children group[1]. One of the main causes of skin disease among children is due to a lack of tissue immunity[4]. The incidence of MCV infection is common in children and low immunosuppressant's[17-19] high rates of infection occurred between children and adolescents younger than 16 years old, Where there is an evidence of a correlation among MCV infection and swim and sports practice for school students[17]. This study was conformed with searchers by [20-22], all of them found that type 1 is the general cause of the illness in children, among age group (110years), MCV type1 prevalence was detected in the younger age and adults .

Fig( 2):- Distribution of patients with MCV by age groups

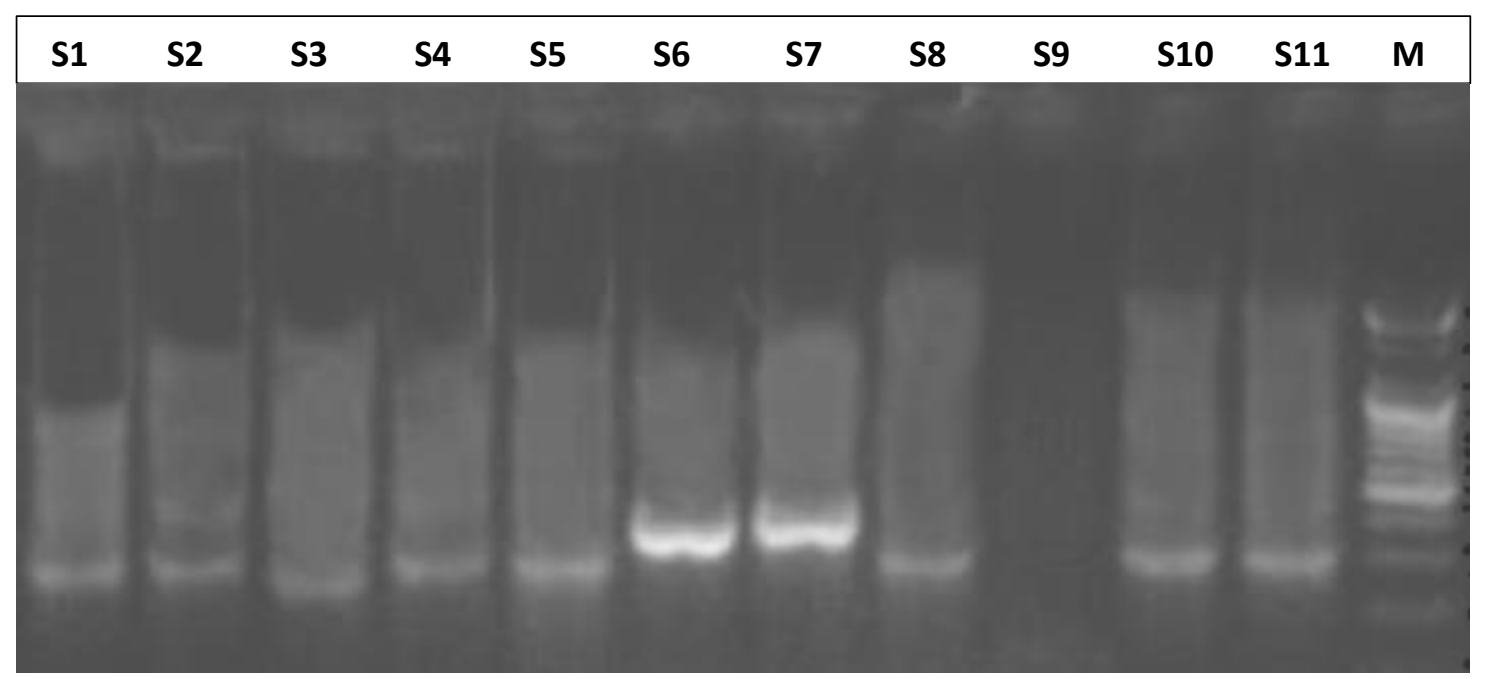

Figure(3):Agarose gel electrophoresis of amplified products for Molluscum lesions (393bp),S:ample ; M:ladder 


\section{Mean Difference of FSAL Concentration by Patients' Medical History}

There was significant Mean Differences of FSAL concentration by MCV's location. It is obvious as shown in table (1) that viral infection localized mostly in their distribution on the hand and face more than other parts of the body and this may related to the exposure of these parts to the external and physical factors such as UV-light, disruption and injury which facilitate the viral entry to the skin [4] $80 \%$ of patients possessed previous MCV disease for less than 1 year, The high concentration of FASL was $80.58 \pm 22.01$ for this group. This indicates that the immunity of the body is high when the disease is repeated. Consistent with his study [13], lesions induced by MCV can go through spontaneous regression within 1-2 years in healthy individual . MCV in immune deficient patients is in charge for more prevalent infections[ 23-24].

Table 1: Mean Difference of FSAL(CD95L) Concentration(pg/ml) by Patients' Medical History

\begin{tabular}{|l|l|l|l|l|}
\hline Variable & $\mathbf{N}$ & Mean \pm SD of FASL & $\begin{array}{l}\text { Test } \\
\text { Value }\end{array}$ & $\begin{array}{l}\boldsymbol{P} \\
\text { values }\end{array}$ \\
\hline $\begin{array}{l}\text { MCV's location } \\
\text { Hand }\end{array}$ & 12 & $75.33 \pm 13.36$ & $\mathbf{2 . 7 9 2}^{\mathbf{a}}$ & $\mathbf{0 . 0 3 9 *}$ \\
Face & 9 & $87.33 \pm 22.22$ & & \\
Neck & 3 & $70.00 \pm 6.92$ & & \\
Foot & 3 & $88.66 \pm 14.10$ & & \\
Head & 3 & $77.33 \pm 24.85$ & & \\
\hline $\begin{array}{l}\text { Previous MCV } \\
<\mathbf{1} \text { year }\end{array}$ & 24 & $80.58 \pm 22.01$ & $0.292^{\mathrm{b}}$ & 0.773 \\
$>\mathbf{1}$ year & 6 & $77.83 \pm 12.53$ & & \\
\hline
\end{tabular}

${ }^{*}$ : Independent sample t-test

${ }^{*} p$ value $\leq 0.05$ is significant

a: ANOVA

\section{Mean Difference of FSAL Concentration between MCV Patients and control group}

Table (2) shows the Mean Difference of FSAL Concentration among MCV Patients' and control group. the evaluation of CD95L protein level at serum of patient with MCV virus revealed high concentration level with Mean $80.06 \mathrm{pg} / \mathrm{ml}$ and low concentration of their level at serum of control group. Mean $28.80 \mathrm{pg} / \mathrm{ml}$. 
Table( 2): Mean Difference of FSAL Concentration between MCV Patients and control group

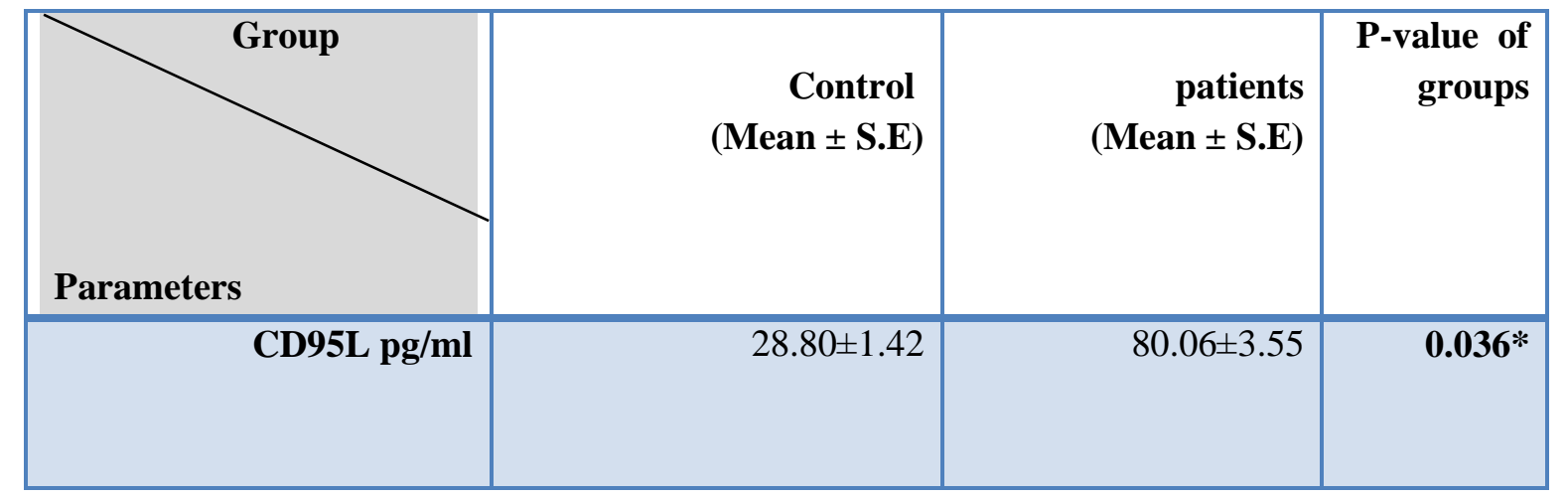

t-test.

$* \mathrm{P} \leq 0.05$.

S.E: Standard error

The body immunity ( Fas ligand) CD95L level was increased at serum of patient than in serum of control group because of the immunity against MCV controlled by cellular immunity mediated by natural killer cell and TNF family, which sequentially induced the production of CD95L( FASL) and the induction of necrosis and killing of viral infected cell .[9],[25] CD951( Fasl) gene is a part of the tumor necrosis factor family. The main purpose of the programmed transmembrane protein is the stimulation of apoptosis mediated by attachment to FAS. The FAS/FASLG indicating passageway which is necessary for the regulation of immune system. Incorporate with activation-induced cell death (AICD) of T cells and cytotoxic $\mathrm{T}$ cell triggering cell death, as well as their vital ability to implicate the development of various cancers. CD951 (Fasl) gene Defects possibly correlated to a few cases of systemic lupus erythematosus (SLE). Otherwise spliced copies variants have been reorganized. [26-27] major genomic types with prevalent spreading during the world had been recognized :-MCV 1 and its minor variant MCV 1, MCV 2, and MCV 3, PCR supported and identify one major MCV types (MCV 1), This type was mostly observed in age group (510 years), after that age group(11-15 years), then age group (16-20years) [28-29] this study excepted with[28] in which about $80 \%$ of the patients was younger than 8 years old, and dissimilarity with[15] which reported that $(62 \%$ $64 \%$ ) of patients go to ages 11-30 years. The prevalent of MCV infection probably due to impairment existing of immune system[30]. On the other hand, this difference in result was due to the growing number of infection occurred in adults with Molluscum contagiosum in present year $\mathrm{s}$ and the information were twofold more than MC infection rate at the last 10 years, this variation of occurrence to type- 1 possibly as a result to the community organization in addition to the dominant social interaction.

\section{$\underline{\text { References }}$}

1-Brown J, Janniger CK and Schwartz RA and Silverberg NB .2006. Childhood Molluscum contagiosum. International Journal of Dermatology 45:93-99

2- van der Wouden JC, van der Sande R, van Suijlekom-Smit LW, Berger M, Butler CC and Koning S .2009. Interventions for cutaneous molluscum contagiosum. The Cochrane Database of Systematic Reviews. (4):CD004767. 
3-Bargman H. 1986. Is genital molluscum contagiosum a cutaneous manifestation of sexual abuse in children? Journal of the American Academy of Dermatology;14(5 Pt 1):847-9.

4- van Haalen FM, Bruggink SC, Gussekloo J, Assendelft WJ and Eekhof JA. .2009. Warts in primary schoolchildren: prevalence and relation with environmental factors. The British Journal of Dermatology;161:148-52.

5- Pierard-Franchimont C, Legrain A and Pierard GE. 1983. Growth and regression of molluscum contagiosum. Journal of the American Academy of Dermatology. Nov;9(5)

6- Chen X, Anstey AV and Bugert JJ. .2013. Molluscum contagiosum virus infection. The Lancet. Infectious Diseases; 13(10): 877-888.

7-Vermi W, Lonardi S, Morassi M et al. .2009. Cutaneous distribution of plasmacytoid dendritic cells in lupus erythematosus. Selective tropism at the site of epithelial apoptotic damage. Immunobiology 214:877-886

8- Garvey TL, Bertin J and Siegel RM, et al. .2002. Binding of FADD and caspase-8 to Molluscum contagiosum virus MC159 v-FLIP is not sufficient for its anti apoptotic function. Journal of Viroliogy.;76(2):697-706.

9- Asanuma K., Tsuji N., Endoh T., Yagihashi A. and Watanabe N. 2004. Survivin Enhances Fas Ligand Expression via Up-Regulation of Specificity Protein 1-Mediated Gene Transcription in Colon. The Journal of Immunology. 172:3922-3929.

10-Cribier B, Scrivener Y and Grosshans E. .2001. Molluscum contagiosum: histologic patterns and associated lesions. A study of 578 cases. The American Journal of Dermatopathology 23:99-103.

11- Ibraheam IA., Saleh IA., Kadhim HJ. and Al-Mahdi ZKA. 2016.Molecular diagnostic of Escherichia coli among urinary tract infection's patients using polymerase chain reaction (PCR). Pakistan journal of Biotechnology .13(4):275-278.

12- Danial W.1999.Probility and T distribution Biostatistics, $7^{\text {th }}$ ed. A foundation for analysis in the health sciences 83-123.

13- Moss B, Shisler JL and Xiang Y et al. .2000. Immune-defense molecules of molluscum contagiosum virus, a human poxvirus. Trends in Microbiology 8:473-477 .

14- Seet BT, Johnston JB and Brunetti CR et al. 2003. Poxviruses and immune evasion. Annual Reviews of Immunology 21:377-423

15- Smith KJ, Yeager J and Skelton H. .1999. Molluscum contagiosum: its clinical, histopathologic, and immunohistochemical spectrum. International Journal of Dermatology;38(9):664-72.

16- Kavita Rao, NS Priya, HS Umadevi and T Smitha. 2013. Molluscum contagiosum. Journal of Oral and Maxillofacial Pathology; 17(1): 146-147. 
17-Olsen JR, Gallacher J, Piguet V and Francis NA. 2014. Epidemiology of Molluscum contagiosum in children: a systematic review. The Journal of Family Practice; 31(2): 130-136.

18-ShislerJL .2015. virus Immune evasion strategies of molluscum contagiosum virus. Advances in Virus Research;92:201-52

19-Stock I. 2013. Molluscum contagiosum--a common but poorly understood childhood disease" and sexually transmitted illness. Med Monatsschr Pharm.;36(8):282-90 (Abstract)

20- Hanson D and Diven DG. .2003.Molluscum contagiosum. Dermatol Online Jornal.;9(2):2.

21- Magdalene AD, Peggy L, Amy S, James L and Lawrence F. .2006.The epidemiology of molluscum contagiosum in children .Journal of the American Academy of Dermatology;54:47-54.

22- Clark Stevens .2009. Molluscum infection information. azian article. Cohen J, Powderly WG. .2004. Infectious Diseases. $2^{\text {nd }}$ ed. New York, NY: Elsevier;:2053- 2056.

23- Cotton DW, Cooper C and Barrett DF et al. .1987. Severe atypical molluscum contagiosum infection in an immunocompromised host. The British Journal of Dermatoogy;l 116:871-876 .

24-Stanford MM and McFadden G. .2005. The 'supervirus'? Lessons from IL-4-expressing poxviruses. Trends in Immunology 26:339.

25-Vermi W, Fisogni S, Salogni L, Schärer L, Kutzner H, Sozzani S, Lonardi S, Rossini C, CalzavaraPinton P, LeBoit PE and Facchetti F. 2011. Spontaneous regression of highly immunogenic Molluscum contagiosum virus (MCV)-induced skin lesions is associated with plasmacytoid dendritic cells and IFN-DC infiltration., Journal of Investigative Dermatology :131(2):426-434...

26- Karray S, Kress C, Cuvellier S, Hue-Beauvais C, Damotte D and Babinet C et al. .2004.Complete loss of Fas ligand gene causes massive lympho proliferation and early death, indicating aresidual activity of gld allele. Journal of Immunology; 172: 2118-2125.

27-Randall RE and Goodbourn S. 2008. Interferons and viruses: an interplay between induction, signalling, antiviral responses and virus countermeasures. Journal of General Virology;89(Pt 1):1-47

28- Chandrashekar L, Devinder M, and Telanseri J. 2003. Clinical profile of molluscum contagiosum in children versus adults. Dermatology online Journal 9 (5): 1

29- Dohil MA, Lin P, Lee J, Lucky AW, Paller AS and Eichenfield LF. 2006.The epidemiology of molluscum contagiosum in children. Journal of the American Academy of Dermatology;54(1):47-54.

30- Kuchabal, D.S. Kuchabal, B. Siddaramappa, P.S.M. Katti and P.V. Patil. 2010. Molluscum Contagiosum a clinical and epidemiological study. Internet Journal Of Dermatology. 8(2) 